\title{
Past distribution of Ursus arctos in Bulgaria: fossil and subfossil records (Carnivora: Ursidae)
}

Минало разпространение на кафявата мечка (Ursus arctos) в България: фосилни и субфосилни данни (Carnivora: Ursidae)

\section{Zlatozar BOEV}

National Museum of Natural History, Bulgarian Academy of Sciences, 1, Blvd. Tsar Osvoboditel, 1000 Sofia, Bulgaria; boev@nmnhs.com; zlatozarboev@gmail.com

received on 13 April 2020

\begin{abstract}
The paper summarizes numerous scattered data from the last 120 years on the former distribution of the brown bear (Ursus arctos) in Bulgaria. Data from 52 (13 fossil and 39 subfossil) sites (from the Middle Pleistocene to the 19th century AD) are presented. The brown bear former distribution was much wider than the present occurrence. The species range covered the whole territory of the country, including mountain regions, as well as vast lowland and plain landscapes. The geographical, altitudinal and chronological distribution are presented and analyzed. The record from the Kozarnika Cave (1.000,000-700,000 years BP) is one of the earliest records of this species in Europe. About 73\% of the localities are situated between 100 and $500 \mathrm{~m}$ a. s. 1. Twelve sites contain Paleolithic finds, one Mesolithic, 14 Neolithic, six Chalcolithic, five from the Bronze Age, and two from the Iron Age. The remaining 12 subrecent sites are dated to the last ca. 2,400 years. Most of the species findings came from archeological sites - prehistoric and ancient settlements. The distribution of Ursus arctos once covered the entire territory of the country, including the vast regions such as Ludogorie, Dobruja, the Danube Lowland, the Upper Thracian Lowland, as well as the Sakar, Strandja, Sredna Gora, and the Predbalkan Mts.
\end{abstract}

Key words. Brown bear, large carnivores, endangered mammals, history of wildlife, Balkans.

\section{INTRODUCTION}

Being the second largest European terrestrial carnivore, the brown bear (Ursus arctos Linnaeus, 1758) left very abundant record in all regions of the continent. Due to its massive bones, it is a taphonomically significant animal. However, in contrast to Ursus spelaeus Rossenmüller, 1794, the fossil/subfossil record of $U$. arctos is surprisingly scarce in Bulgaria. Moreover, it has not been subject of a special research so far.

The former wide distribution of Ursus arctos in Europe contrasts with the present-day highly shrunk range. At present, the territory of Bulgaria is considered one of the most important parts of the range (SPASOv 2007) for the conservation of this impressive species in Europe. The current national population numbers around 415-555 individuals and the species status in Bulgaria is reported as "endangered" (Spasov 2007, Spiridonov \& Spassov 2015). Its recent range in Bulgaria is split into three separated parts (Fig. 1) in the Rila-Rhodopes Mountains, Central Stara Planina Mts., and Western Stara Planina Mts. (SpiRIdonov \& Spassov 2015). 


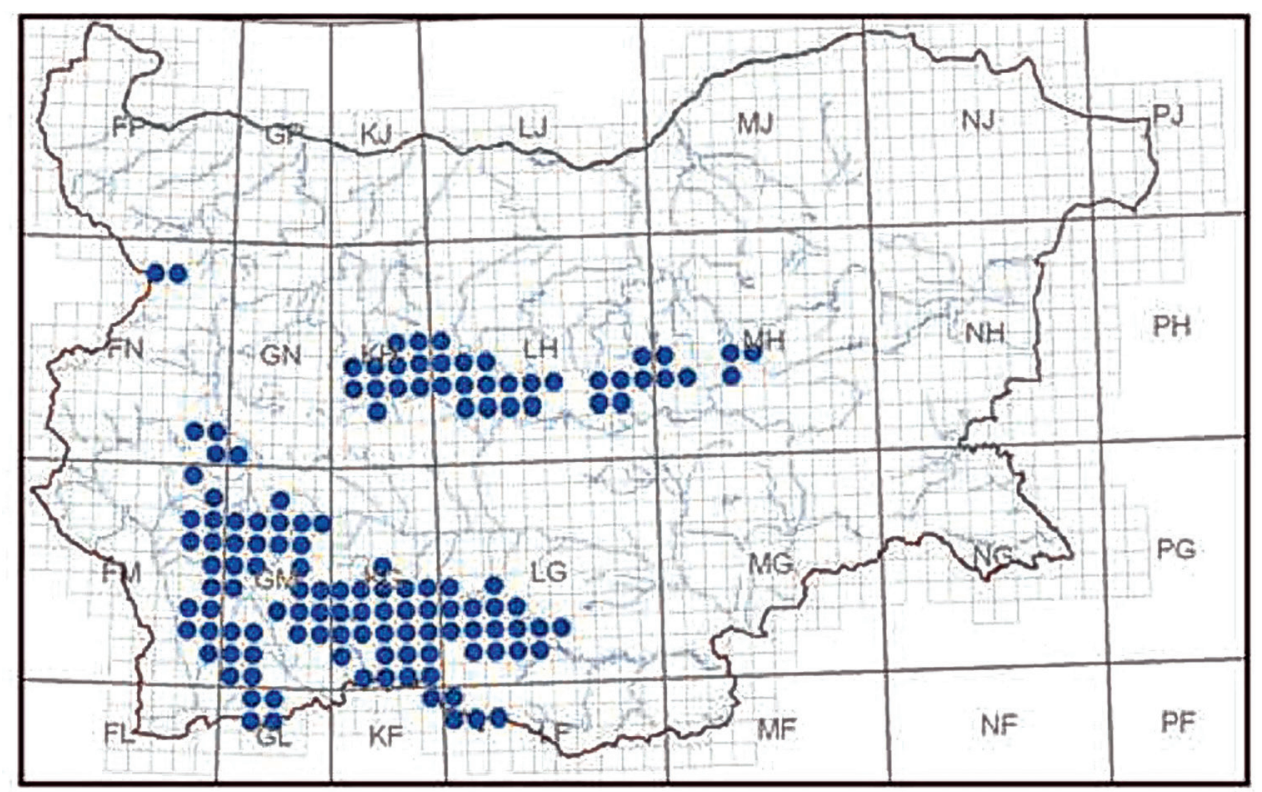

Fig. 1. Present range of $U$. arctos in Bulgaria (after SpiRIDONov \& Spassov 2015).

Фиг. 1. Съвременно разпространение на U. arctos в България (по SPIRIDONov \& Spassov 2015).

Although some publications deal with the origin, past dispersal and distribution of Ursus arctos in Bulgaria and the Balkan Peninsula as well, none of them has presented summary data on its past distribution so far. This paper aims to gather scattered data (some of them in less accessible sources) on the former distribution of the brown bear in Bulgaria for the first time, based on its fossil/subfossil record. The abundant historical records since medieval ages till the subrecent times remain beyond its scope. Some of the finds were published in some less accessible archaeological editions which remained unknown to the zoological community. They thus represent a valuable source for elucidating the former distribution of one of the most popular wild animals in the Balkans.

Note. Until 2020, records of the total of eight species of the genus Ursus Linnaeus, 1758 have been reported from Bulgaria. Along with Ursus arctos, remains of U. savini Andrews, 1922 (Gurova et al. 2016, 2017, 2018, Guadelli et al. 2014), U. etruscus Cuvier, 1823 (Guadelli et al. 2005), U. deningeri von Reichenau, 1904 (GuAdelli et al. 2005, TANEVA et al. 2005), U. ingressus Rabeder, Hofreiter, Nagel et Withalm, 2004 (Georgiev et al. 2010, Ivanova et al. 2016), U. minimus Devèze et Bouillet, 1827 / U. etruscus (Spassov 1997a, 2003), U. minimus / U. thibetanus Cuvier, 1823 (Spassov 2000), U. cf. thibetanus (Gurova et al., 2017), the most numerous U. spelaeus (BERON et al. 2006, GuAdell et al. 2005), and even Ursus sp. (StoÂnov 1904, Popov 1933, Guadelli \& Delpech 2000) have been identified from excavations all over the country. In addition, Popov $(1931,1936)$ reported on occurrence of the ninth species of a bear, Ursus arctoideus Reichenau, 1904 (now a synonym of $U$. deningeri), from the Toplâ Cave. It should be mentioned that most of the Pleistocene remains of U. spelaeus from Bulgaria are now referred to U. ingressus (N. SPASSOv - in litt.). 


\section{MATERIAL AND METHODS}

I tried to gather all scattered published and unpublished data on the former distribution of the brown bear in the present day territory of Bulgaria. For each site I present as complete data as possible on the age, excavations, and the reference to the original published information. The great majority of bear bone/teeth finds (Fig. 2) came from the excavated archeological sites of ancient and medieval human settlements. The site No. 41 (Serdika) represents in fact two different localities - Forum Serdika (3th-19th century AD) and the Northern Wall of the Serdika Citadel (3rd-6th century AD), both situated in the present city centre of Sofia.

The chronostratigraphy (Table 1) follows CoHEn et al. (2013): (1) Chibanian (Middle Pleistocene, 770,000-129,000 years BP); (2) Late Pleistocene (129,000-11,700 years BP); (3) Holocene (11,700 years BP - Recent) - Greenlandian (Early Holocene, 11,700-8,200 years BP), Northgrippian (Middle Holocene, 8,200-4,200 years BP), Meghalayan (Late Holocene, 4,200 years BP - present). The archaeological periodization follows VladiKov (1992): Early Paleolithic (400,000-100,000 years BP), Midle Paleolithic $(100,000-40,000$ years BP), Late Paleolithic (40,000-10,000 years BP), Mesolithic $(10,000-7,000$ years BP), Neolithic (7,000-5,500 years BP), Chalcolithic (5,500-3,500 years BP), Bronze Age (3,500-1,200 years BP), Iron Age (1,200-900 years BP). The historical epoch is divided into the Hellenic period, Roman period, Byzantine period, and Medieval period (Table 1).

Abbreviations used: AD - Anno Domini, BC - before Christ; BP - before present, c. - century.

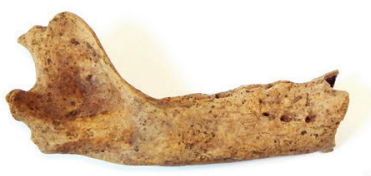

a
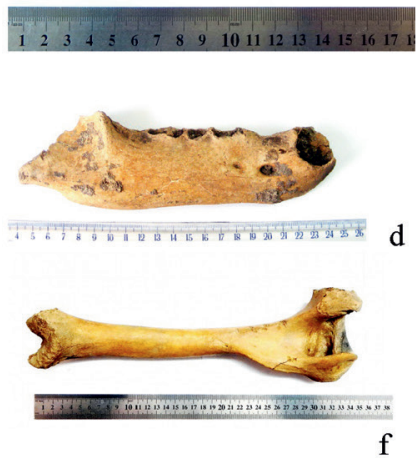

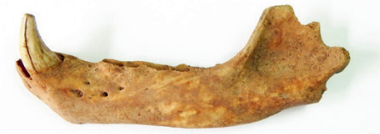

b

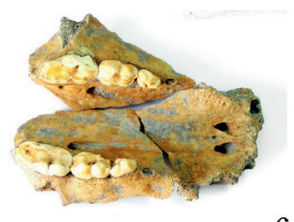

c d
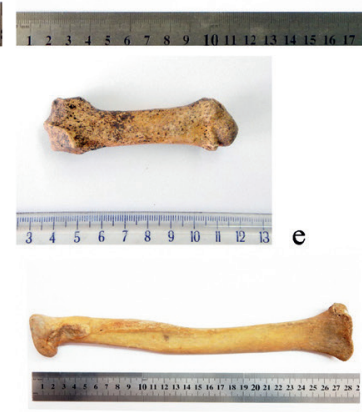

$\mathrm{g}$

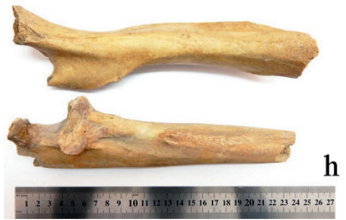

Fig. 2. Subfossil bone remains of Ursus arctos from some archeological sites in Bulgaria: (a) mandibula dex. - Serdika, Sofiâ; (b) mandibula sin. - Serdika, Sofiâ; (c) maxilla dex. and maxilla sin. - Mursalevo; (d) mandibula dex. - Mursalevo; (e) metacarpalia 1 dex. - Mursalevo; (f) humerus dex. - Sedica, Sofiâ; (g) radius sin. - Serdika, Sofiâ; (h) femur dex. and ulna dex. - Serdika, Sofiâ. Photos by Z. Boev.

Фиг. 2. Субфосилни костни останки от Ursus arctos от някои археологични находища в България: (a) mandibula dex. - Сердика, София; (b) mandibula sin. - Сердика, София; (c) maxilla dex. и maxilla sin. - Мурсалево; (d) mandibula dex. - Мурсалево; (е) metacarpalia 1 dex. - Мурсалево; (f) humerus dex. - Сердика, София; (g) radius sin. - Сердика, София; (h) femur dex. и ulna dex. - Сердика, София. Снимки 3. Бовв. 


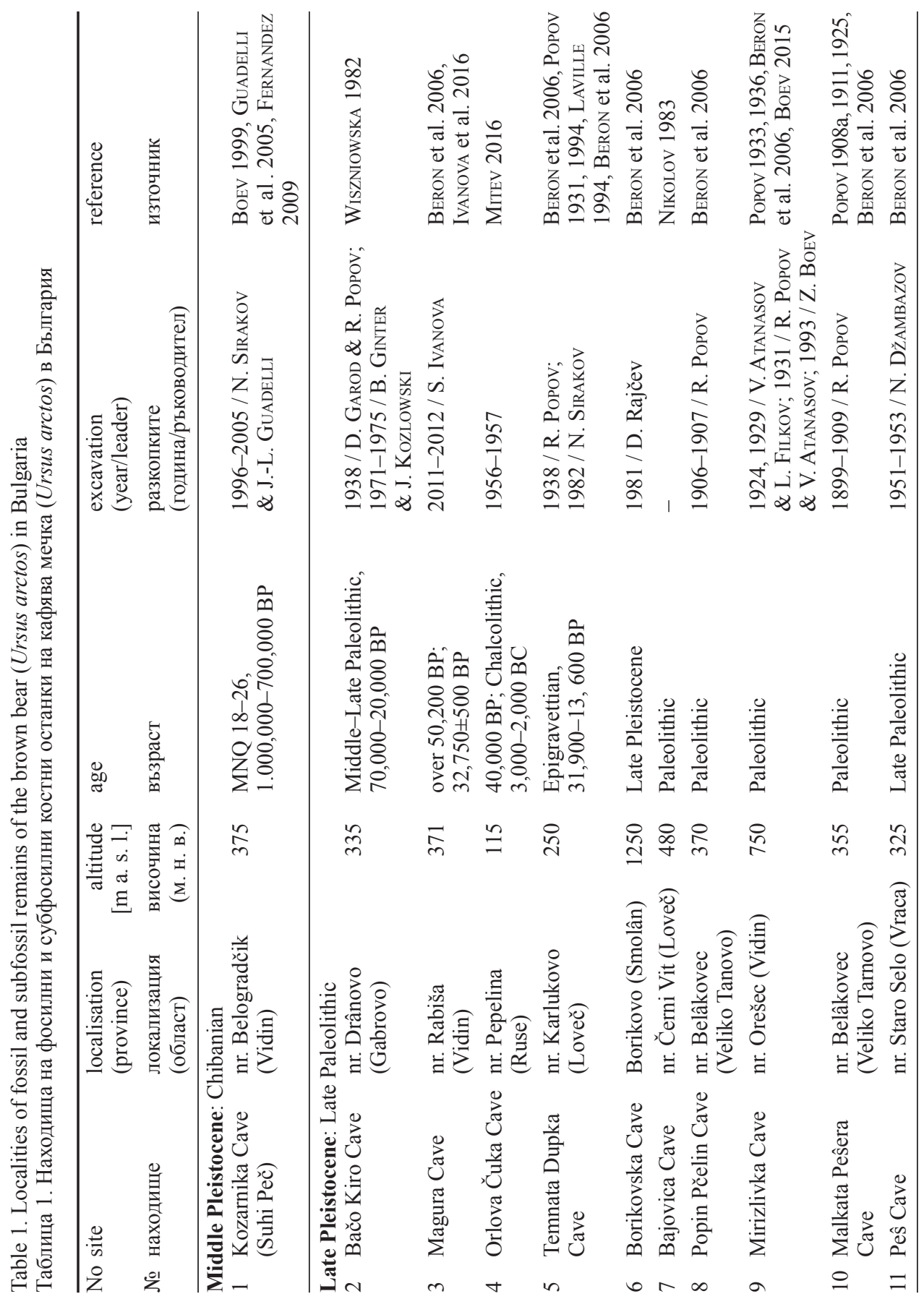




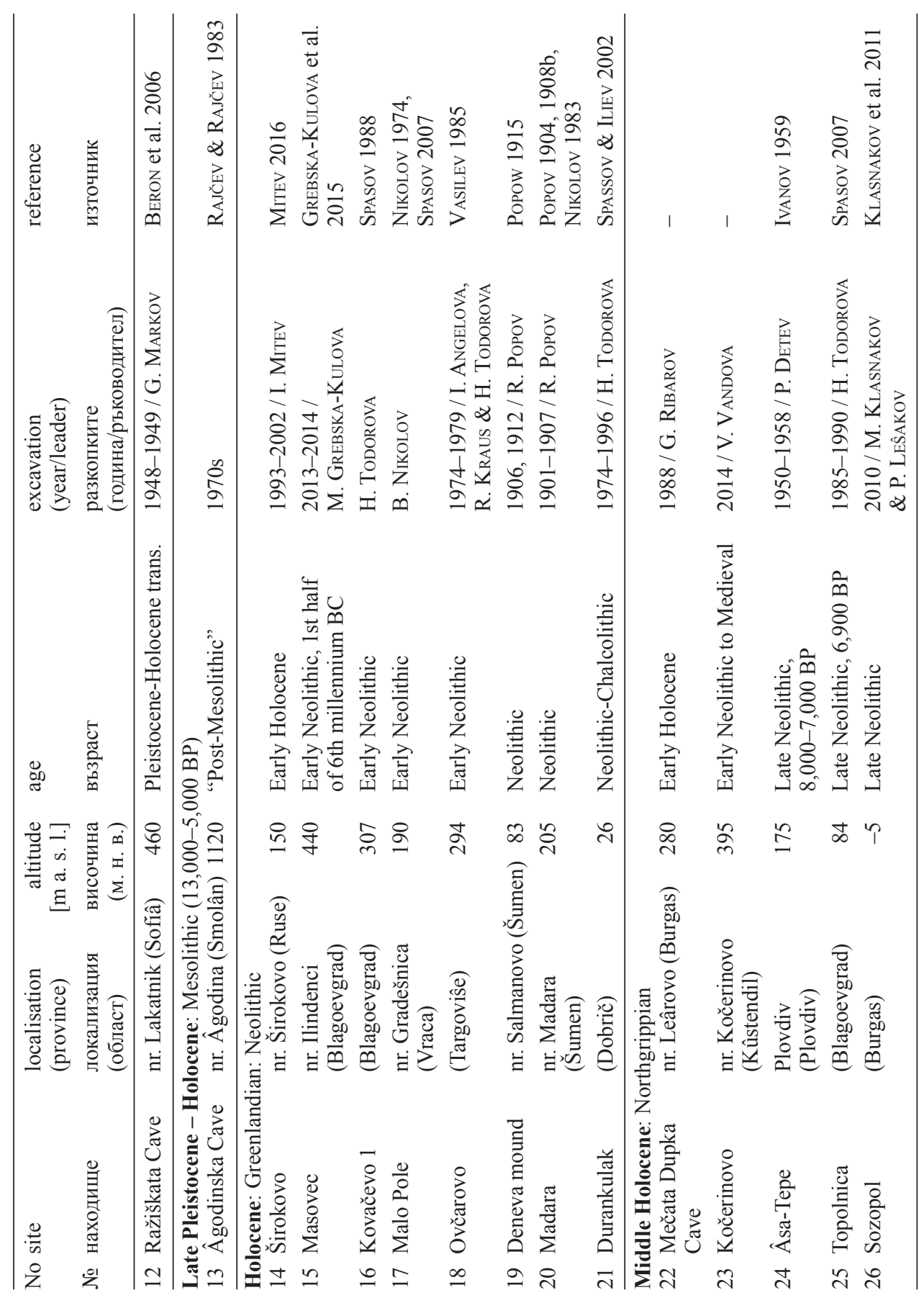




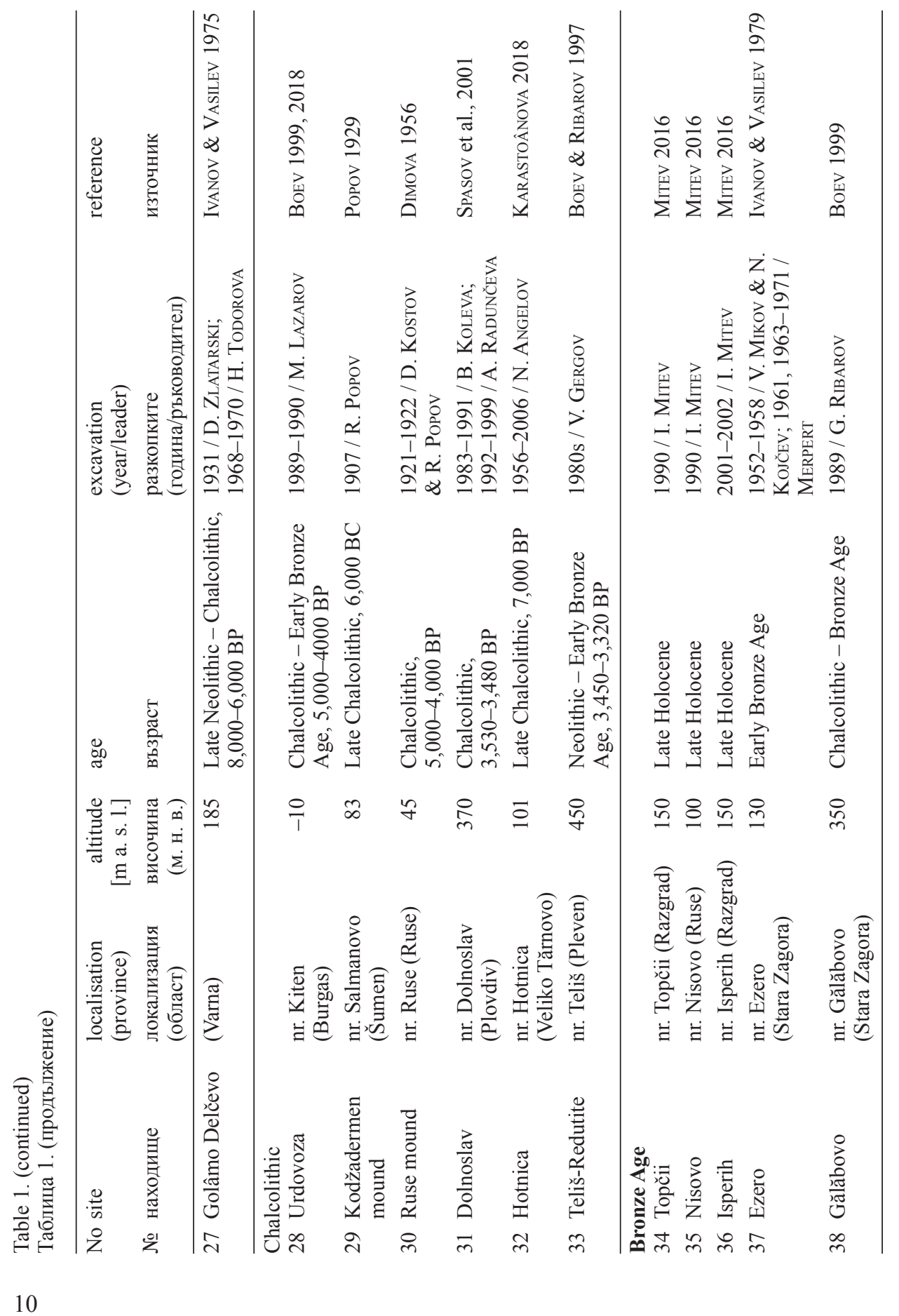




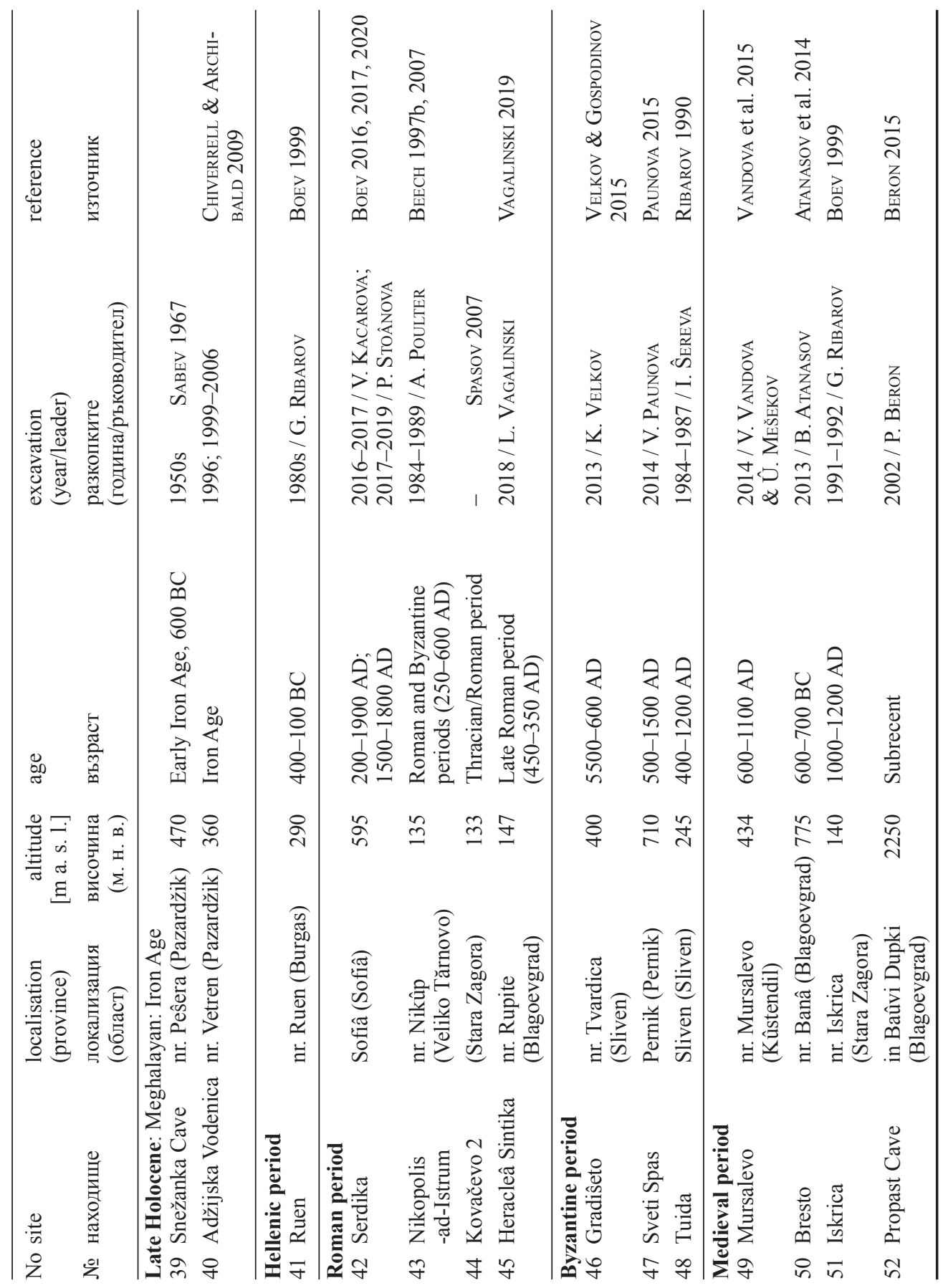




\section{RESULTS AND DISCUSSION}

Ursus arctos appeared as a species in the Middle Pleistocene, its range covered most of Eurasia, Northern Africa and North America (Gromova et al. 1962, Gromov \& BArAnova 1981). The Balkan brown bears are assigned to the nominate subspecies $U$. a. arctos Linnaeus, 1758. After GeNOv (2017) results of the molecular genetic analyses joined the Balkan brown bears with the bears of the eastern Alps, Apennines, and the Pyrenees (ERSMARK et al. 2019). The Bulgarian and all south-European bears are considered as relicts of the late Pleistocene (SpaSsOv 1997b). They are adapted to mountain landscapes in contrast to bears of northeastern Europe, inhabiting vast taiga plains since the end of the Pleistocene (SPASSOv 1997a). ErsmarK et al. (2019) state that the "Bulgarian" (Balkan) brown bears were widely spread over Europe in the Late Pleistocene.

There are two important factors determining the representativeness of the former bear distribution - movement capability of the animals and the possibility of human transportation of bear body remains. Tracked bears from Bulgaria traveled a distance of $73 \mathrm{~km}$ in eight months, covering a range of ca. $90 \mathrm{~km}^{2}$; an average range of juvenile males in Bulgaria is $266 \mathrm{~km}^{2}$ (GENOv 2017). Having in mind that adult brown bears are large animals with heavy body (adult males from Bulgaria weigh up to $350 \mathrm{~kg}$; SpASOv 2007), we may conclude that almost all sites of the excavated bone remains - but not teeth - reflect relatively exactly the real former distribution of the bears. There is no reason for the ancient hunters to transfer the heavy carcasses or body parts (legs, heads) far from the sites of the killing of animals and utilization of their body parts. It is also inconsistent to assume that bears traveled further away from their natural home ranges than now. Presumably, their natural environment was much richer than the present one.

So far only one Bulgarian site revealed record of Ursus arctos of the Middle Pleistocene age. These oldest finds came from the Kozarnika Cave, dated to the "limit between the Early and the Middle Pleistocene" (1.000,000-700,000 years BP; FernAndez 2009: 59). This is one of the oldest European records of the brown bear at all.

A total of 12 sites of the bear fossils are of the Late Pleistocene age. Eleven of them are of the Late Paleolithic and one of the Mesolithic period. Seven Early Holocene sites revealed bone remains of Ursus arctos from the Neolithic and only one site (Širokovo) is of a non-anthropogenic origin. A total of twelve sites yielded finds of brown bears dated to the Neolithic (1), Chalcolithic (6), and from the Bronze Age (5), see Table 1.

A total of 14 sites revealed finds of brown bears dated to the period covering the Iron Age to the subrecent time. Two of them are of the Iron Age, three are from the Byzantine (and medieval) settlements, and four are medieval; i.e. of the post-Byzantine (7-12 century AD), Hellenic, and Roman/Thracian sites (Table 1). Only one site (Propast Cave) is a natural bone accumulation. Four sites (Mursalevo, Kočerinovo, and Serdika I and II) are here reported for the first time, they were excavated in the last six years.

The altitudinal distribution of the fossil and subfossil brown bear in Bulgaria is surprisingly wide - from $-10 \mathrm{~m}$ to $2,250 \mathrm{~m}$ a. s. 1. (Table 1 ). Only three sites are situated above $1000 \mathrm{~m}$ a. s. 1., while the great majority of localities $(\mathrm{n}=45 ; 73.1 \%)$ lie below $500 \mathrm{~m}$ a. s. 1 . and only four sites are situated at 500-1,000 m a. s. 1. Most of the documented sites of the brown bear in the Holocene were located at 100-400 m a. s. $1 .(\mathrm{n}=31 ; 65.4 \%)$. The Holocene range of Ursus arctos included the whole territory of the country (Fig. 3). Two Holocene sites (Sozopol and Urdoviza) are nowadays sunk in the Black Sea ( -5 and $-10 \mathrm{~m}$ below sea level, respectively).

The Pleistocene localities of Ursus arctos in Bulgaria are concentrated in two main mountain massifs - the Stara Planina Mts. and Western Rhodopes Mts. The only exception is the Orlova 


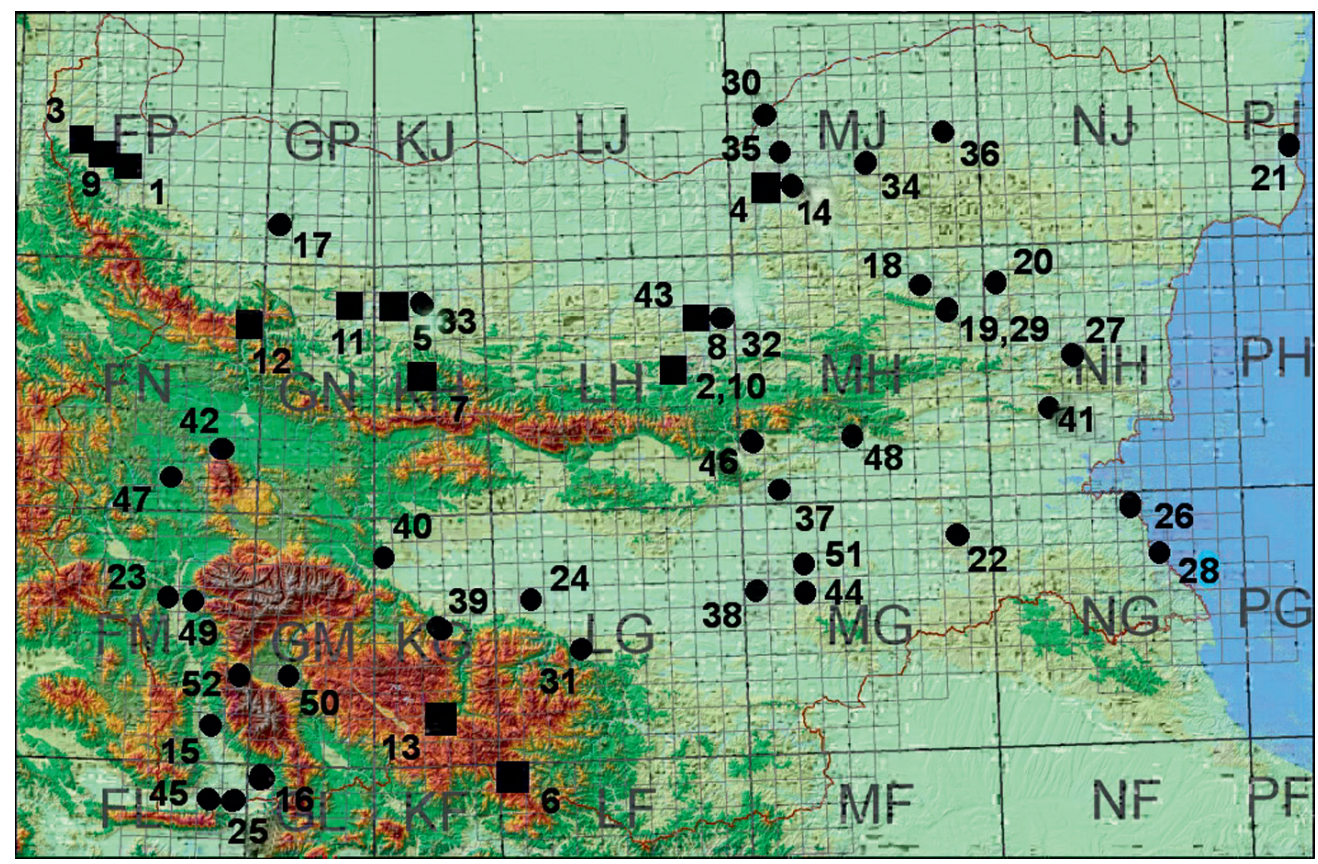

Fig. 3. Former distribution of Ursus arctos in Bulgaria. Numbers correspond to the list of localities in the text: Pleistocene (squares): (1) Kozarnika (Suhi Peč) Cave, (2) Bačo Kiro Cave, (3) Magura Cave, (4) Orlova Čuka Cave, (5) Temnata Dupka Cave, (6) Borikovska Cave, (7) Bajovica Cave, (8) Popin Pčelin Cave, (9) Mirizlivka Cave, (10) Malkata Peŝera Cave, (11) Peŝ Cave, (12) Ražiškata Cave, (13) Âgodinska Cave; Holocene (circles): (14) Širokovo, (15) Masovec, (16) Kovačevo 1, (17) Malo Pole, (18) Ovčarovo, (19) Deneva mound, (20) Madara, (21) Durankulak, (22) Mečata Dupka Cave, (23) Kočerinovo, Âsa-Tepe (24), (25) Topolnica, (26) Sozopol, (27) Golâmo Delčevo, (28) Urdovoza, (29) Kodžadermen settlement mound, (30) Ruse mound, (31) Dolnoslav, (32) Hotnica, (33) Teliš-Redutite, (34) Topčii, (35) Nisovo, (36) Isperih, (37) Ezero, (38) Gălăbovo, (39) Snežanka Cave, (40) Adžijska Vodenica, (41) Ruen, (42) Serdika, (43) Nikopolis-ad-Istrum, (44) Kovačevo 2, (45) Herakleâ-Sintika, (46) Gradiŝeto, (47) Sveti Spas, (48) Tuida, (49) Mursalevo, (50) Bresto, (51) Iskrica, (52) Propast Cave.

Фиг. 3. Минало разпространение на Ursus arctos в България. Номерацията отговаря на находищата в текста: Плейстоцен (квадратчета): (1) Пещера Козарника (Сухи Печ), (2) Пещера Бачо Kиро Cave, (3) Пещера Магурата, (4) Пещера Орлова Чука, (5) Пещера Темната Дупка, (6) Бориковска пещера, (7) Пещера Байовица, (8) Пещера Попин Пчелин, (9) Пещера Миризливка, (10) Малката пещера, (11) Пещера Пещ, (12) Ражишка пещера, (13) Ягодинска пещера; Холоцен (кръгчета): (14) Широково, (15) Масовец, (16) Ковачево 1, (17) Мало Поле, (18) Овчарово, (19) Денева селищна могила, (20) Мадара, (21) Дуранкулак, (22) Пещера Мечата дупка, (23) Кочериново, (24) Ясъ-Тепе, (25) Тополница, (26) Созопол, (27) Голямо Делчево, (28) Урдовиза, (29) Коджадерменска селищна могила, (30) Русенска селищна могила, (31) Долнослав, (32) Хотница, (33) Телиш-Редутите, (34) Топчии, (35) Нисово, (36) Исперих, (37) Езеро, (38) Гълъбово, (39) Пещера Снежанка, (40) Аджийска воденица, (41) Руен, (42) Сердика, (43) Никополис ад Иструм, (44) Ковачево 2, (45) Градището, (46) Хераклея Синтика, (47) Свети Спас, (48) Туида, (49) Мурсалево, (50) Бресто, (51) Искрица, (52) Пещера Пропаст. 
Cuka Cave in north-eastern Bulgaria. The fossil and subfossil record of the brown bear clearly proves a much wider former distribution of the species, not only in the mountain regions, but also in the vast lowland and plain landscapes as the Upper Thracian Lowland, Ludogorie, and Dobruja. Also three other mountain ranges, Sredna Gora, Sakar, and Strandja, as well as the Predbalkan Mts. were parts of the former species range. This review thus confirms the earlier SPASOV's (2007) conclusion that the brown bear was widespread over most of the country in the Neolithic to the Iron Age. Until the 19th century AD, the brown bear still inhabited the large regions of the Ludogorie and Strandja Mts. in the east of the country, and the Stara Planina population was connected through the Ihtimanska Sredna Gora Mts. with the Rila-Rodopes bear population.

The fossil/subfossil record of the brown bear confirmed its former distribution in 22 provinces of the total of 28 in the country, while at present the species range encompasses parts of only nine provinces (Spiridonov \& Spassov 2015), ca. a quarter of the former range.

\section{SUMMARY}

Статията обобщава множество разпръснати данни за миналото разпространение на кафявата мечка в България от последните 120 години, част от които са непубликувани. Представени са данни от 52 находища (13 фосилни и 39 субфосилни) от среден плейстоцен до 19 век н. е. от 22 от общо 28-те области в страната. Представени и анализирани са географското, височинното и хронологичното разпространение. Около 73 \% от находищата са разположени между 100 и 500 м. н. в. 12 находища съдържат палеолитни находки, 1 мезолитни, 14 неолитни, 6 халколитни, 5 от бронзовата епоха, и 2 от желязната епоха. Останалите 12 субрецентни находища са датирани от последните ок. 2400 години. Находките от пещерата Козарника (1,000.000-700.000 г.) са едни от най-древните свидетелства за вида в Европа. Повечето от установените находки на вида произлизат от археологически обекти - праисторически и древни селища. Разпространението на вида някога обхващало цялата територия на страната, вкл. и обширни райони като Лудогорието, Добруджа, Дунавската равнина, Горно-Тракийската низина, както и планините Сакар, Странджа и Средна гора и Предбалкана.

\section{REFERENCES}

Atanasov B., Kulov I., Gorčik J., Bineva V., Etien J., Velkovski K., Dimitrova N., Dimitrov M., Džurkovska G., Ivanov S., Ilieva E., Kopp D., Lepek M., Marinova E., Todorova N., Stoev D., Uzunov Z., Tsvetanov Â. \& Stockhammer P., 2014: Proučvaniâ v m. Bresto, s. Banâ, Obŝina Razlog [Studies in Bresto near Banâ village, Municipality of Razlog]. Pp.: 115-118. In: Gûrova M. (ed.): Arheologičeski otkritiâ i razkopki prez 2013 g. [Archeological Discoveries and Excavations in 2013]. TDG Print, Sofia, 911 pp (in Bulgarian).

BeECH M., 1997: The economy and environment of a Roman, late-Roman and early Byzantine town in North-Central Bulgaria: the mammalian fauna from Nicopolis-ad-Istrum. Anthropozoologica, 25-26: 619-630.

Beech M., 2007: The large mammal and reptile bones. Pp.: 154-197. In: Poulter A. (ed.): Nicopolis ad Istrum III: A Late Roman and Early Byzantine City: The Finds and the Biological Remains. Oxbow Books, London, $320 \mathrm{pp}$.

Beron P., 2015: Cave Fauna of Bulgaria. East-West Publishing, Sofia, 440 pp.

Beron P., Daaliev T. \& Jalov A., 2006: Caves and Speleology in Bulgaria. Pensoft Publishers, Sofia, 507 pp.

Boev Z., 1999: Neogenski i kvaternerni ptici (Aves) ot Bălgariâ [Neogene and Quaternary Birds (Aves) of Bulgaria]. Bălgarskata akademiâ na naukite, Sofiâ, 243+135+108 pp (in Bulgarian). 
Boev Z., 2015: Fossil and subfossil remains of birds and mammals from the Mirizlivka cave (Vidin Region - NW Bulgaria). ZooNotes, 75: 1-3.

Boev Z., 2016: Subfossil vertebrate fauna from Forum Serdica (Sofia, Bulgaria), 16-18th century. Acta Zoologica Bulgarica, 68: 415-424.

Boev Z., 2017: New data on the subfossil fauna from "Forum Serdica" (Sofia City, Bulgaria; 3-19th century A.D.). Historia Naturalis Bulgarica, 24: 179-186.

Boev Z., 2018: Fossil and subfossil record of vertebrate animals (Vertebrata J.-B. Lamarck, 1801) along the western Black Sea coast (Bulgaria). In: Georgieva E. \& Peev D. (eds.): Proceedings of the First European Symposium "Research, Conservation and Management of Biodiversity of European Seashores (RCMBES)". Acta Zoologica Bulgarica, Supplement 11: 105-110.

Boev Z., 2020: New data on the fauna of the Late Antiquity Northern Fortification walls of Serdica (3rd6th century A.D.) from building excavations on Exarch Joseph Street (Sofia, Bulgaria). Bulletin of the Natural History Museum - Plovdiv, 5: 15-23.

Boev Z. \& Ribarov G., 1997: Kostni ostanki ot divi i domašni životni ot praistoričeskoto seliŝe "TelišRedutite" pri s. Teliš (Plevensko) [Bone remains of wild and domestic animals from the Teliš-Redutite prehistoric settlement near Teliš (Pleven District)]. Historia Naturalis Bulgarica, 7: 61-70 (in Bulgarian).

Chiverrell R. \& Archibald Z., 2009: Human activity and landscape change at Adjiyska Vodenitsa, Central Bulgaria. Géomorphologie: Relief, Processus, Environnement, 4: 287-302.

Cohen K. M., Finney S. C., Gibbard P. L. \& Fan J.-X., 2013: The ICS International Chronostratigraphic Chart. Episodes, 36: 199-204.

Dıмova V., 1956: Seliŝnata mogila kraj Ruse [A settlement mound near Ruse]. Nauka i Tehnika za Mladežta, 7: 3-4 (in Bulgarian).

Ersmark E., Baryshnikov G., Higham T., Argant A., Castanos P., Doppes D., Gasparik M., Germonpre M., Liden K., Lipecki G., Marciszak A., Miller R., Moreno-Garcfa M, Pacher M., Robu M., RodriguezVarela R., Rojo Guerra M., Sabol M., Spassov N., Stora J., Valdiosera, C., Villaluenga A., Stewart J. \& DALEN L., 2019: Genetic turnovers and northern survival during the last glacial maximum in European brown bears. Ecology and Evolution, 9: 5891-5905.

Fernandez P., 2009: Mammalian dynamics and palaeoecological analysis during the Pleistocene in Kozarnika Cave (Bulgaria). Pp.: 59-73. In: Gatsov I. \& Guadelli J.-L. (ed.): Saxa Loquuntur, Collected Works Honoring Nikolay Sirakov's 65th Anniversary. Avalon, Sofia, 339 pp.

Genov P., 2017: Mečkata (proizhod, legendi, vârvaniâ, folklore, biologiâ i ekologiâ) [The Bear (Origin, Legends, Beliefs, Folklors, Biology, and Ecology)]. Knižen tiger, Sofiâ, 400 pp (in Bulgarian).

Georgiev D., Yankov L., Stoycheva S., Delev S., Zhelev P., Pavlova A. \& Zagorska M., 2010: New localities of Quaternary fossil bears (Ursus sp. L.) (Mammalia: Carnivora: Ursidae). ZooNotes, 8: 1-4.

Grebska-Kulova M., Zidarov P., Vasilev I., Salanova L., Vieguer J., Marinova-Wolf E., de Couper B. \& Ivanova R., 2015: Razkopki na praistoričeskoto seliŝe v m. Masovec, s. Ilindenci, Obŝina Strumâni [Excavations of a prehistoric settlement in Masovec, Ilindenci village, Strumâni municipality]. Pp.: 56-59. In: KABAKČıEva G. (ed.): Arheologičeski otkritiâ i razkopki prez 2014 g. [Archeological Discoveries and Excavations in 2013]. Aktiv Komers EOOD, Sofiâ, 912 pp (in Bulgarian).

Gromov I. \& Baranova G. (eds.), 1981: Katalog mlekopitaûsih SSSR (pliocen-sovremennost') [Catalogue of the Mammals of the Soviet Union (Pliocene-Present)]. Nauka, Leningrad, $456 \mathrm{pp}$ (in Russian).

Gromova V. I., Dubrovo I. A. \& ÂnovskaÂ N. M., 1962: Otrâd Carnivora. Hiŝnie [Order Carnivora. Carnivores]. Pp.: 182-230. In: Gromova V. I. (ed.). Osnovy paleontologii. Tom 13. Mlekopitaûsie [Basic Palaeontology. Volume 13. Mammals]. Izdatel'stvo Akademii nauka SSSR, Moskva, 423 pp (in Russian).

Guadelli J.-L. \& Delpech F., 2000: Les grands mammiferes du debut du paleolithique superieur a Temnata. Pp.: 53-158. In: Ginter B., Kozlowski J. K., Guadelli J.-L. \& Laville, H. (eds.): Temnata Cave. Excavations in Karlukovo Karst Area, Bulgaria. Volume 2. Part 1. Jagellonian University, Cracow, 418 pp.

Guadelli J.-L., Sirakov N., Ivanova S., Sirakova S., Anastassova E., Courtaud P., Dimitrova I., Duabarska N., Fernandez P., Ferrier C., Fontugne M., Gambier D., Guadelli A., Iordanova D., Iordanova N., Kovatcheva M., Krumov I., Leblanc J.-C., Mallye J.-B., Marinska M., Miteva V., Popov V., Spassov 
R., Taneva S., Tisterat-Laborde N. \& Tsanova T., 2005: Une séquence du paléolithique inférieur au paléolithique récent dans les Balkans: la grotte Kozarnika à Orechets (Nord-Ouest de la Bulgarie). British Archaeological Reports, 1364: 87-103.

Guadelli A., Guadelli J.-L., Sirakov N., Krumov I. \& Mitov K., 2014: Proučvaniâ na paleolita v peŝerata Redaka II, Belogradčiško [Investigation of the Paleolithic in the Redaka II Cave, Belogradčik Province]. Pp.: 30-31. In: KABAKČIEVA G. (ed.): Arheologičeski otkritiâ i razkopki prez 2013 g. [Archeological Discoveries and Excavations in 2013]. Aktiv Komers EOOD, Sofia, 911 pp (in Bulgarian).

Gurova M., Ivanova S., Spasov N., Hristova L., Krumov I., Verheiden S., Marinova E. \& Dedov I., 2016: Razkopki v peŝerata Mišin kamak: 3 sezon [Excavations at the Mišin Kamak Cave: season 3]. Pp: 56-59. In: Aladžov A. (ed.): Arheologičeski otkritiâ i razkopki prez 2015 g. [Archeological Discoveries and Excavations in 2015]. Multiptint, Sofia, 985 pp (in Bulgarian).

Gurova M., Ivanova S., Spasov N., Hristova L., Popov V., Marinova E. \& Bohme M., 2017: Razkopki v peŝerata Mišin kamak: 4 sezon [Excavations at the Mišin Kamak Cave: season 4]. Pp.: 48-50. In: VAgalinski L. (ed.): Arheologičeski otkritiâ i razkopki prez 2016 g. [Archeological Discoveries and Excavations in 2016]. Bulged Ltd, Sofiâ, 801 pp (in Bulgarian).

Gurova M., Ivanova S., Marinova E., Popov V., Spasov N., Hristova L., Verheiden S. \& Burlet C., 2018: Razkopki v peŝerata Mišin kamak: 5 sezon [Excavations at the Mišin Kamak Cave: season 5]. Pp.: 8-11. In: VAGALINSKI L. (ed.): Arheologičeski otkritiâ i razkopki prez 2017 g. [Archeological Discoveries and Excavations in 2017]. Bulged Ltd., Sofiâ, 912 pp (in Bulgarian).

Ivanov S., 1959: Divite i domašnite životni v bita na naselenieto ot Âsa-Tepe v Plovdiv [Wild and domestic animals in the everyday life of the population of Âsa-Tepe in Plovdiv]. Annuel du Musée National d'Archéologie - Plovdiv, 3: 81-85 (in Bulgarian).

Ivanov S. \& VASILEV V., 1975: Proučvaniâ na životinskiâ kosten material ot praistoričeskata deliŝna mogila pri Golâmo Delčevo [Studies of the animal bone material from the prehistoric mound near Golâmo Delčevo]. In: Todorova H., Ivanov S., Vasilev V., Hopf M., Quitta H. \& Koll G. (eds.): Deliŝna mogila pri Golâmo Delčevo [Mound near Golâmo Delchevo]. Razkopki i Proučvaniâ, 5: 245-302 (in Bulgarian).

IVANOv S. \& VASILEV V., 1979: Proučvaniâ na životinskite kostni ostataci [Investigations of the animal bone remains]. Pp.: 425-490. In: Georgriev G., Merpert N., Katinčarov R. \& Dimitrov D. (eds.): Ezero, rannobronzovoto selisise [Ezero, Early Bronze Age Settlement]. Bălgarskata akademiâ na naukite, Sofiâ, 549 pp (in Bulgarian).

Ivanova S., Gurova M., Spasov N., Hristova L., Tzankov N., Popov V., Marinova E., Makedonska J., Smith V., Ottoni C. \& Lewis M., 2016: Magura Cave, Bulgaria: A multidisciplinary study of Late Pleistocene human palaeoenvironment in the Balkans. Quaternary International, 415: 86-108.

KARASTOÂNOVA N., 2018: Razvitie na lova $i$ životnovadstvoto $i$ razliki v prirodnata obstanovka ot kasnia neolit do kasnia halkolit v Iztočna Bălgaria po danni ot arheologičeski obekti [Development of Hunting and Animal Husbandry and Differences in the Environment Between the Late Neolithic to the Late Chalcolithic in the Eastern Bulgaria after the Data from Archaeological Sites]. Unpubl. PhD. Thesis. Nacionalen Prirodonaučen Muzej, Sofiâ, 221 pp (in Bulgarian).

Klasnakov M., Leŝakov P., Samičkova G., Aleksandrova R., Spasov N. \& Zlateva R., 2011: Spasitelno arheologičesko proučvane na kasnoneolitnoto seliŝe Budžaka v zonata na UPI 8033, gr. Sozopol, Burgaska oblast [Salvage archeological study of the late Neolithic settlement Budžaka in the zone of UPI 8033, town of Sozopol, Burgas Province]. Pp.: 65-68. In: Gûrova M. (ed.): Arheologičeski otkritiâ i razkopki prez $2010 \mathrm{~g}$. [Archeological Discoveries and Excavations in 2010]. Avangard, Sofiâ, 597 pp (in Bulgarian).

Mitev I., 2016: Subfosilna fauna ot ptici i bozajnici (Aves et Mammalia - Vertebrata) ot nahodiŝa v Severoiztočna Bălgariâ [Subfossil fauna of birds and mammals (Aves et Mammalia-Vertebrata) from the localities in north-eastern Bulgaria]. Pp.: 203-691. In: Boev Z. (ed.): Ivan Mitev. Sabrani trudove. Tom 1. Bălgarska priroda [Ivan Mitev. Collected Works. Volume 1. Bulgarian Nature]. Logis, Sofiâ, 904 pp (in Bulgarian).

Nikolov B., 1974: Gradešnica.Praistoričeski seliŝa [Gradešnica.Prehistoric Settlements]. Nauka i izkustvo, Sofiâ, 143 pp (in Bulgarian). 
NIKOLOv I., 1983: Nâkoj beležki varhu peŝernata fosilna bozajna fauna v Bălgariâ [Some notes on the cave fossil mammalian fauna in Bulgaria]. Pp.: 215-218. In: DINEv L. (ed.): Četvarta evropejska regionalna konferenciâ po speleologiâ, septemvri, 1980 [Fourth European Regional Conference of Speleology, September 1980]. Bălgarska federaciâ po pešterno delo, Sofia, 403 pp (in Bulgarian).

PAunOva V., 2015: Rannohristânska bazilika, kasnosredovekoven i vazroždenski nekropol v m. Sveti Spas, kvartal Varoš, gr. Pernik [Early Christian basilica, late middle ages and renaissance necropolis in the Sveti Spas locality, Varosh quarter, town of Pernik]. Pp: 742-744. In: KaBAKČIEVA G. (ed.): Arheologičeski otkritiâ i razkopki prez 2014 g. [Archeological Discoveries and Excavations in 2014]. Aktiv Komers EOOD, Sofiâ, 912 pp (in Bulgarian).

Popov R., 1904: Prinos kăm predistoriata na Bălgaria (peŝerite v Tărnovskia Dervent, seliŝeto Madara i peŝerite nad Šumen) [A contribution to the prehistory of Bulgaria (the caves of the Tărnovo Dervent, the settlement of Madara and the caves above Šmen]. Sbornik za Narodni Umotvorenia, 20: 1-27 (in Bulgarian).

Popov R., 1908a: Prinos kam neolitnata bozajna fauna v Bălgariâ [A contribution to the Neolithic mammalian fauna of Bulgaria]. Sbornik ot Narodni Umotvoreniâ, Nauka i Knižnina, 12: 1-22 (in Bulgarian).

Popov R., 1908b: Prinos kam predistoriata na Bălgariâ [A contribution to the prehistory of Bulgaria]. Sbornik ot Narodni Umotvoreniâ, Nauka i Knižnina, 24: 1-19 (in Bulgarian).

Popov R., 1911: Malkata peŝera v Tărnovskiâ dervent [Malkata Cave in the Tărnovo Dervent]. Estestvoznanie, 3: 148-166 (in Bulgarian).

Popov R., 1925: Belâkovskoto plato. Peŝeri i doistoričeski seliŝa [Belâkovsko plateau. Caves and prehistoric settlements]. Izdaniâ na Narodniâ Muzej v Sofiâ, 3: 1-58 (in Bulgarian).

Popov R., 1929: Doistoričeska Bălgariâ [Prehistorical Bulgaria]. Hristo Danov, Sofiâ, 76 pp (in Bulgarian).

Popov R., 1931: Temnata dupka - novo nahodiŝe ot paleolita v Bălgariâ [Temnata Dupka - a new locality of the Paleolithic in Bulgaria]. Izdaniâ na Narodniâ Arheologičeski Muzej v Sofiâ, 24: 1-148 (in Bulgarian).

Popov R., 1933: Peŝerata Mirizlivka. Prinos kam diluvialnata fauna i kulturata na diluvialniâ čovek [Mirizlivka Cave. A contribution to the diluvial fauna and the culture of the diluvial man]. Izdaniâ na Narodniâ Arheologičeski Muzej, 26: 1-74 (in Bulgarian).

Popov R., 1936: Fosilni i subfosilni životinski ostanki v izsledvanite do sega peŝeri na Bălgariâ [Fossil and subfossil animal remains in the caves of Bulgaria studied so far]. Izvestiâ na Bălgarskoto Peŝerno Družestvo, 1: 1-12 (in Bulgarian).

Popow R., 1915: Predistoričeskata Deneva mogila pri s. Salmanovo [The prehistoric Deneva mound near the Salmanovo village]. Izvestiâ na Bălgarskoto Arheologičesko Družestvo, 4: 148-225 (in Bulgarian).

RAJČEV D., \& RAJČEV G. 1983: Âgodinskiât karstov rajon [Âgodinski Karst Region]. Medicina i fizkultura, Sofiâ, 48 pp (in Bulgarian).

RiBAROv G., 1990: Bozajnicite v bita na žitelite na rannovizantijskoto i srednovekovno seliŝe na Hisarlaka (Sliven) [Mammals in the everyday life of the inhabitants of the early Byzantine and medieval settlement on Hisarlaka (Sliven)]. Arheologiâ, 4: 50-58 (in Bulgarian).

Spasov N., 1988: Perspektivi na arheozoologičnite izsledvaniâ na neolitnoto nahodiŝe do s. Kovačevo (kraj gr. Petrič) i problem na razvitieto na holocenskata bozajna fauna $v$ ûgoiztočna Evropa [Perspectives of the Archaeozoological Studies of a Neolithic Site near Kovačevo Village (near the Town of Petrič) and the Problems of the Development of the Holocene Mammalian Fauna in Southeastern Europe]. Unpubl. Report. Joint French-Bulgarian Archeological Expedition "Kovačevo", Sofiâ, 7 pp (in Bulgarian).

Spasov N., 2007: Mečka Ursus arctos (Linnaeus, 1758) [Brown bear Ursus arctos (Linnaeus, 1758)]. Pp.: 239-249. In: Popov V., Spassov N., Ivanova T., Minova B. \& Georgiev K. (eds.): Bozajnicite važni za opazvane v Bălgariâ [Mammals Important for Conservation in Bulgaria]. Dutch Mammal Society VZZ, Sofiâ, 328 pp (in Bulgarian).

Spasov N., ILIEv N. \& Boev Z., 2001: Životinski ostanki ot eneolitniâ arheologičeski obekt kraj s. Dolnoslav, Plovdivska oblast [Animal remains from the Eneolithic site near the village of Dolnoslav, Plovdiv District, South Bulgaria]. Historia Naturalis Bulgarica, 13: 159-179 (in Bulgarian). 
Spassov N., 1997a: Evidences for a late Pleistocene isolation and a separate taxonomic status of the Mediterranean brown bear and the conservation value of the Balkan bear population. Historia Naturalis Bulgarica, 7: 109-113.

Spassov N., 1997b: Varshets and Slivnitsa - new localities of Villafranchian vertebrate fauna from Bulgaria (taxonomic composition, biostratigraphy and climatochronology). Geologica Balcanica, 27(1-2): 83-90.

SpASSOv N., 2000: Biochronology and zoogeographic affinities of the Villafranchian faunas of Bulgaria and south Europe. Historia Naturalis Bulgarica, 12: 89-128.

Spassov N., 2003: The Plio-Pleistocene vertebrate fauna in south-eastern Europe and the megafaunal migratory waves from the east to Europe. Revue de Paléobiologie, Geneve, 22: 197-229.

Spassov N. \& Iliev N., 2002: The animal bones from the prehistoric necropolis near Durankulak (NE Bulgaria) and the latest record of Equus hydruntinus Regalia. Pp.: 313-324. In: Todorova H. (ed.): Die prähistorischen Graberfelder von Durankulak. Band II. Teil 1. Anubis, Sofia, 360 pp.

Spiridonov G. \& Spassov N. 2015: Brown bear Ursus arctos L., 1758. P.: 153. In: Golemanski V. (ed.): Red Data Book of the Republic of Bulgaria. Volume 2. Animals. IBER BAS \& MOEW, Sofia, 383 pp.

STоÂNOv I., 1904: Prinos kam predistoriâta na Bălgariâ. Peŝerata Toplâ, Golâma Železna [A contribution to the prehistory of Bulgaria. Toplâ Cave near Golâma Železna]. Trudove na Bălgarskoto Prirodoizpitatelno Družestvo, 2: 100-139 (in Bulgarian).

Taneva S., KovaČEva N., Dimitrova, I. \& Spasov R., 2005: Terenni izdirvaniâ na paleolitni obekti v rajona na Strandža [Field research of Paleolithic objects in the region of Strandja]. P.: 17. In: NIKov K. (ed.): Arheologičeski otkritiâ i razkopki prez 2004 g. [Archeological Discoveries and Excavations in 2004]. Anubis, Sofiâ, 333 pp (in Bulgarian).

VAGalinski L., 2019: Herakleâ Sintika [Heraclea Sintika]. Pp: 273-276. In: Popov H. (ed.): Arheologičeski otkritiâ i razkopki prez 2018 g. [Archeological Discoveries and Excavations in 2018]. Bulged Ltd., Sofiâ, 787 pp (in Bulgarian).

Vandova V., Mešekov Û., Spasov R., Anastasova E., Mitkova R., Stefanova T., Todorov V., AtanasovaTimeva N., Galabova B. \& Boev Z., 2015: Spasitelni arheologičeski razkopki v m. Gerena pri s. Mursalevo [Salvage archaeological excavations in the Gerena locality near the Mursalevo village]. Pp.: 51-53. In: KABAKČIEVA G. (ed.): Arheologičeski otkritiâ i razkopki prez 2014 g. [Archeological Discoveries and Excavations in 2004]. Aktiv Komers Ltd., Sofiâ, 912 pp (in Bulgarian).

VASILEV V., 1985: Izsledvaniâ na faunata ot seliŝna mogila Ovčarovo [Studies of the fauna of the Ovčarovo settlement mound]. Interdisciplinarni Izsledvaniâ, Sofiâ, 13: 1-200 (in Bulgarian).

VeLKov K. \& Gospodinov N., 2015: Redovni arheologičeski proučvaniâ v m. Gradiŝeto severoiztočno ot Tvardica [Regular archeological explorations in the Gradiŝeto locality, northeast of the Tvardica town]. Pp.: 694-695. In: KABAKČIEVA G. (ed.): Arheologičeski otkritiâ i razkopki prez 2014 g. [Archeological Discoveries and Excavations in 2004]. Aktiv Komers Ltd., Sofiâ, 912 pp (in Bulgarian).

VladiKov E., 1992: Grafična istoriâ na Balkanskite narodi [Graphical History of the Balkan Peoples]. Sofijski Universitet "Sv. Kliment Ohridski”, Sofiâ, 40 pp (in Bulgarian).

Wiszniowska T., 1982: Carnivora. Pp.: 52-55. In: Kowalski K. (ed.): Excavation in Bacho Kiro Cave (Bulgaria). Final report. Państwowe wydawnictwo naukowe, Warszawa, 172 pp. 